\title{
Safety criteria for the acquisition of meat in Brazilian University restaurants
}

\author{
Marizete Oliveira de MESQUITA ${ }^{1,2 *}$, Leadir Lucy Martins FRIES ${ }^{2}$, Thiele VALENTE ${ }^{3}$
}

\begin{abstract}
The present study's objective was to analyze the procedures aimed at guaranteeing sanitary conditions when acquiring meat. The study was conducted with university restaurants of the Federal Institutions of Higher Education (IFES) located in the five regions of Brazil. Data were collected using a questionnaire and an evaluation list, which was available online to restaurant professionals. The results showed that restaurants chose one or two types of meat, the most frequent of which were beef and chicken. In restaurants managed by the IFES, the acquisition of raw material occurred by bidding. For vendor selection, the restaurants required product registration with the Inspection Service and requested regulation of the supplier by the Health Surveillance. Monitoring was carried out through a technical visit to the supplier and a review of the past records of the supplier. A higher percentage of restaurants in the Southeast region met appropriate sanitary and hygienic criteria for the receipt of meat, followed by the South, Midwest, Northeast and North. We conclude that restaurants meet most of the safety criteria set in the legislation. However, some weaknesses are evident in the physical and functional structure, the system of transportation of raw material and the records of control measures at the place of reception.
\end{abstract}

Keywords: food quality; food services; food safety.

\section{Introduction}

The Brazilian population has undergone major social transformation in recent decades, resulting in changes in physical spaces for sharing meals and daily practices of food preparation (Brasil, 2008b). Among some facilities where meals are consumed outside the home, university campus restaurants of the Federal Institutions for Higher Education (IFES) have the responsibility to ensure right to adequate safety of food (Brasil, 2008a).

The sanitary quality of products offered by food services is an important issue for the individual and population health because many food poisoning outbreaks occur when food is prepared for large groups (Codex Alimentarius Comission, 1993). In Brazil, restaurants rank second in number of reported foodborne illness outbreaks. An epidemiological analysis of 8451 outbreaks of foodborne illnesses reported by the Ministry of Health between 2000 and 2011 revealed that foods of animal origin were the most commonly involved foods in the outbreaks (Brasil, 2011).

Foodborne illnesses associated with food services are related to the hygienic-sanitary quality of food premises (World Health Organization, 2009). Studies conducted in institutional and commercial restaurants in Brazil and other countries show that food services do not always comply with regulations concerning sanitary conditions. This non-compliance includes violations of basic aspects of current legislation, such as inadequate physical infrastructure, lack of management control and monitoring, and restricted capabilities (Luning et al., 2013; Losito et al., 2011; Youn \& Sneed, 2003; Veiros et al., 2009; Akutsu et al.,
2005; São José et al., 2011; Esperança \& Marchioni, 2011; Silva \& Cardoso, 2011).

Supplier selection and the procurement of inputs have low levels of compliance with the current Brazilian Normative Instruction (Medeiros et al., 2012). Obtaining raw material from unreliable sources is a risk factor that contributes to the outbreaks of foodborne illnesses (Food and Drug Administration, 2009). A special focus should be placed on raw food of animal origin, which is considered particularly dangerous (Ebone et al., 2011). Fresh beef, when handled under inadequate sanitary conditions, can be a primary source of infection (Almeida et al., 2010). Thus, the quality of meat depends on the adoption of control measures and monitoring from the pre-slaughter period up to the meat consumption. All parties involved in the supply of meat should ensure the quality of the products (Conceição \& Gonçalves, 2009).

In food services, the receipt of raw material is important to guarantee the safety of the final product (Silva \& Cardoso, 2011; Associação Brasileira de Normas Técnicas, 2008). Therefore, it is imperative to adapt it in order to follow to the principles of good practice, particularly the reception area, process control, and supplier evaluation, and transport system. This is above and beyond the technical visits and observation of the adequacy of the transportation system utilized (Associação Brasileira de Normas Técnicas, 2008; Agência Nacional de Vigilância Sanitária, 2004). The procedures still do not include laboratory tests to establish whether the products are suitable for use to ensure that only suitable products that are in good conditions

${ }^{1}$ Nutrition Course, Franciscan University Center - UNIFRA, Santa Maria, RS, Brazil, e-mail: marizetedemesquita@gmail.com

${ }^{2}$ Graduate Program in Science and Food Technology, Federal University of Santa Maria - UFSM, Santa Maria, RS, Brazil

${ }^{3}$ Food Technology Course, Federal University of Santa Maria - UFSM, Santa Maria, RS, Brazil

${ }^{*}$ Corresponding author 
are used in the preparation of foods (Codex Alimentarius Comission, 2009).

This study aimed to investigate the procedures used to ensure the sanitary conditions of the raw materials in the reception of meat in university campus restaurants in Federal Institutions for Higher Education (IFES) in the North, Northeast, Midwest, Southeast, and South regions of Brazil.

\section{Materials and methods}

\subsection{Research place and studied population}

The present study was conducted from September 2011 to February 2012 in university campus restaurants of IFES located in the five regions of Brazil (North, Northeast, Midwest, Southeast, and South). All operating IFES institutions $(\mathrm{N}=59)$ were contacted by e-mail and phone calls to verify the existence of a university campus restaurant in the institution. It was found that some institutions $(\mathrm{n}=14)$ did not have restaurants in the campus. The restaurants run by an outsourcer company without direct supervision by the IFES ( $n=8$ of the existing IFES restaurants, $n=45$ ) were excluded. The university campus restaurants that were run directly by the IFES or by an outsourcer company that is under the direct supervision of the IFES were included. The party responsible for the participating restaurants $(n=35)$ completed a form agreeing to the terms of the research.

The final samples of restaurants were classified by convenience according to the number of meals served daily: small size, less than 1000 meals/day; midsize, from 1000 to 5000 meals/day; and large size, more than 5000 meals/day.

\subsection{Research instruments}

The research instrument consisted of four blocks; the first three blocks consisted of a questionnaire with closed-ended questions and two open-ended questions (type and number of meals served). The fourth block consisted of an evaluation list with two response options: proper or improper. The fourth block also included one closed-ended question about the laboratory testing of raw materials (response options: yes or no) and one open-ended question (about the type of laboratory testing and the place where it is performed).

Block I included university restaurant identification data. Block II addressed the types of meat used. The data from block III included the acquisition of raw materials. Finally, block IV asked about Good Practice procedures for the receipt of raw materials, as recommended by federal law (transportation of raw materials (Agência Nacional de Vigilância Sanitária, 2004), reception area, quality control, and handling (Agência Nacional de Vigilância Sanitária, 2002)). This research instrument was previously tested in a university restaurant run by the IFES of Rio Grande do Sul.

The method proposed by Saccol et al. (2012) was used in the evaluation of adherence to Good Practice guidelines for the receipt of raw material (block IV). The Grand Total of the items analyzed and the total of the suitable items were considered. The statistic used was the ratio between the total of the suitable items and the Grand Total of the items analyzed multiplied by 100 , and the result was expressed as a percentage. The restaurant facilities were classified according to the compliance percentage: Very Good - 91.0-100.0\%; Good - 70.0-90.0\%; Regular - 50.0-69.0\%; Poor - 20.0-49.0\%; and Very Poor - 0.0-19.0\% (Saccol et al., 2012).

\subsection{Data collecting and ethical aspects}

The consent form of the research project was available online; thus, the restaurant nutritionist could easily complete it. Data gathering was performed using a tool that was developed specifically for this study and was available online from September 2011 to February 2012. The forms were completed by the restaurant nutritionist, and the results were accessed by e-mail.

The Committee of Ethics and Research of the Federal University of Santa Maria approved the ethical and methodological aspects of the research on September 13, 2011 (CAAE 0209.0.243.000-11).

\subsection{Statistical analysis}

Descriptive statistics (absolute frequency, mean, and median) was used with the IBM PASW Statistical version 18 . For comparison between the categorical variables, the Fisher' Exact Test was used at 5\% level of significance (Lopes et al., 2008).

\section{Results}

A total of 71 (seventy-one) university campus restaurants serving approximately 135000 meals/day were investigated; they were located in the following regions: North (7505), Northeast (27297), Midwest (10444), Southeast (48910), and South (40875). The results show that one or more choices of meat were available in those restaurants. Beef and chicken were offered more than once a week in most restaurants (Figure 1).

The data analysis demonstrated significant differences between their management systems, such as the procedure for the acquisition of raw material $(p=0.002)$ and the key suppliers $(p=0.049)$. In IFES-managed restaurants $(n=20)$, the acquisition of raw material in $95.0 \%$ of locations occurred through the form

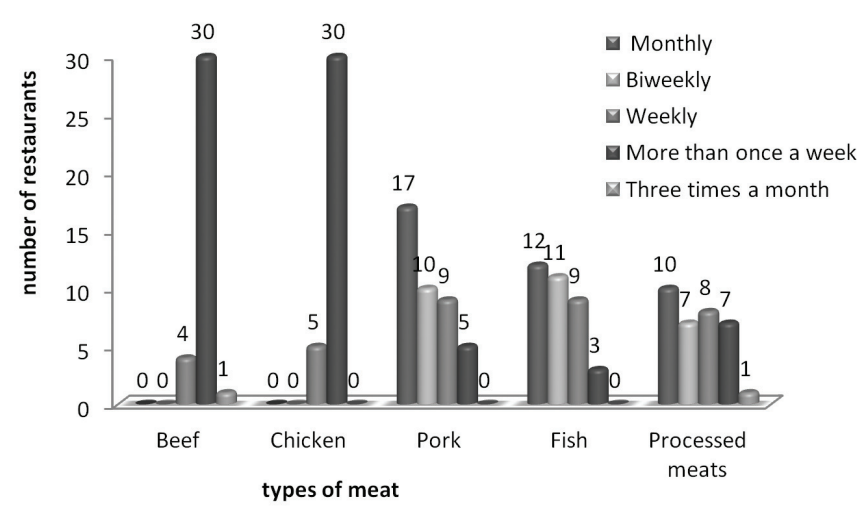

Figure 1. Different types of meat displayed on the menu as a function of the number of university campus restaurants in Federal Institutions of Higher Education in the five regions of Brazil. 
of competitive bidding, in which the selection criterion for the product is the lowest price. In this case, the meat was supplied by slaughterhouses/cold stores (10.0\%), wholesalers (25.0\%), or manifold suppliers (65.0\%). As for the outsourced restaurants $(\mathrm{n}=15)$, the meat was purchased directly from the supplier (40.0\%), through competitive bidding (33.3\%), without bidding (13.3\%), or through other procedures (13.3\%). Cold stores were the major suppliers in $46.6 \%$ of these restaurants.

As shown in Table 1, the nutritionist and his or her staff were responsible for handling food in most restaurants $(n=27)$ and participated in the supervision over sanitation and hygiene matters $(n=18)$ during the receipt of the meats. The most frequently mentioned hygienic and sanitary requirements for the supplier were the requirement of product registration by the Inspection Service $(\mathrm{n}=11)$ and supplier regulation by the Health Surveillance Agency $(n=16)$. The main monitoring activities were the technical visit and the records on suppliers.

It was found that the transport system had major flaws. The certificate of inspection for the meat carrier vehicle and the personal hygiene of the suppliers were inadequate in approximately half of the sites $(n=17)$. Most restaurants had adequate reception areas $(n>30)$. The North region differed from the other regions $(p<0.050)$; it showed weaknesses regarding cleanness and isolation of the reception area. It is worth mentioning that slightly more than half of the restaurants had suitable drains $(\mathrm{n}=19)$, doors, windows, and sinks for personal hygiene $(n=20)$ (Table 2).

Each restaurant had established criteria for the selection of raw material, which was inspected at the reception area $(n=34)$, and the supervisory technical employee carried the identity and quality standards of the products available $(\mathrm{n}=32)$. The North region also differed from the other regions $(\mathrm{p}<0.050)$ because the restaurants did not keep records of the monitoring on spreadsheets. Nevertheless, only half of the restaurants evaluated monitored the temperature of the meat upon reception. As for the product packaging, most establishments assessed integrity $(\mathrm{n}=34)$, the absence of hazards and food safety risks $(\mathrm{n}=32)$ and labeling $(n=33)$. It was found that $25.7 \%$ of restaurants $(n=9)$ had a recycling program for the meat packaging, of which $14.3 \%$ were located in the Southeast ( $\mathrm{n}=5), 5.7 \%$ in the Midwest $(\mathrm{n}=2)$, and $5.7 \%$ in the South region $(n=2)$. The North and Northeast regions differentiated themselves from the others $(\mathrm{p}<0.020)$ by not recycling product packages.

All of the restaurants used raw materials in good condition, and most of them adequately returned meat that was not in good condition $(\mathrm{n}=34)$, meat handlers wore protective clothing $(\mathrm{n}=31)$, washed their hands properly $(\mathrm{n}=29)$, and used sanitized utensils/equipment $(n=34)$ (Table 2$)$. However, only $2(5.7 \%)$ restaurants routinely performed laboratory tests for quality control of meat acquisition.

Table 1. Acquisition of meat in university restaurants of Federal Institutions of Higher Education in the five regions of Brazil.

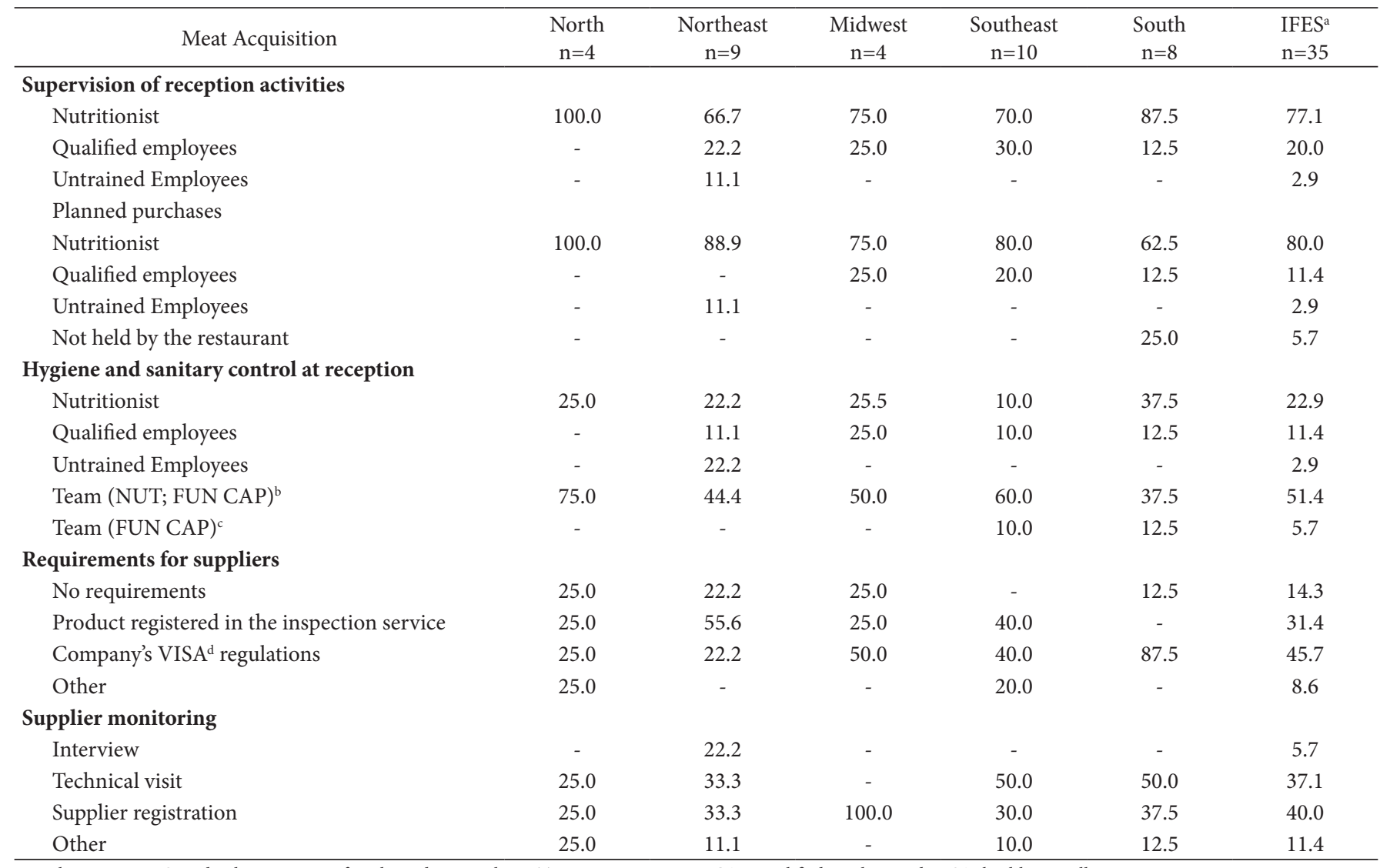

Results in \%. a-IFES- Federal Institutions of Higher Education. b-NUT- Nutritionist; c-FUN CAP- qualified employees; d-VISA- health surveillance. 
Table 2. Reception of meat in university campus restaurants of Federal Institutions of Higher Education in the five regions of Brazil.

\begin{tabular}{|c|c|c|c|c|c|c|c|}
\hline Reception of meat & $\begin{array}{c}\text { North } \\
\mathrm{n}=4\end{array}$ & $\begin{array}{c}\text { Northeast } \\
\mathrm{n}=9\end{array}$ & $\begin{array}{c}\text { Midwest } \\
\mathrm{n}=4\end{array}$ & $\begin{array}{c}\text { Southeast } \\
\mathrm{n}=10\end{array}$ & $\begin{array}{c}\text { South } \\
\mathrm{n}=8\end{array}$ & $\begin{array}{l}\text { IFES }^{\mathrm{a}} \\
\mathrm{n}=35\end{array}$ & $p^{\mathrm{b}}$ \\
\hline \multicolumn{8}{|l|}{ Raw material transportation } \\
\hline Hygiene, Vehicle maintenance & 75.0 & 55.6 & 75.0 & 90.0 & 75.0 & 74.3 & 0.583 \\
\hline Private cabin in the vehicle & 75.0 & 88.9 & 50.0 & 90.0 & 87.5 & 82.9 & 0.308 \\
\hline Has certificate of inspection & 25.0 & 44.4 & 25.0 & 60.0 & 62.5 & 48.6 & 0.567 \\
\hline Delivery personnel properly attired and/or groomed & 25.0 & 44.4 & 75.0 & 60.0 & 37.5 & 48.6 & 0.316 \\
\hline \multicolumn{8}{|l|}{ Reception area } \\
\hline Clean and isolated & 50.0 & 100.0 & 100.0 & 100.0 & 87.5 & 91.4 & 0.023 \\
\hline Wide, ventilated, easy access & 50.0 & 77.8 & 100.0 & 100.0 & 87.5 & 85.7 & 0.116 \\
\hline Covered area & 100.0 & 100.0 & 75.0 & 100.0 & 87.5 & 94.3 & 0.202 \\
\hline \multicolumn{8}{|l|}{ Quality control } \\
\hline Preestablished criteria & 100.0 & 88.9 & 100.0 & 100.0 & 100.0 & 97.1 & 0.714 \\
\hline Inspection and approval & 75.0 & 100.0 & 100.0 & 100.0 & 100.0 & 97.1 & 0.229 \\
\hline $\begin{array}{l}\text { Technician has features of identity standards and } \\
\text { quality of raw materials available }\end{array}$ & 100.0 & 77.8 & 75.0 & 100.0 & 100.0 & 91.4 & 0.218 \\
\hline Control spreadsheets & - & 33.3 & 75.0 & 90.0 & 37.5 & 51.4 & 0.008 \\
\hline Controlled temperature & 25.0 & 33.3 & 50.0 & 80.0 & 50.0 & 51.4 & 0.252 \\
\hline Package integrity & 100.0 & 88.9 & 100.0 & 100.0 & 100.0 & 97.1 & 0.714 \\
\hline Labeling according to legislation & 100.0 & 77.8 & 100.0 & 100.0 & 100.0 & 94.3 & 0.383 \\
\hline $\begin{array}{l}\text { Non-hazardous raw material that cannot be reduced } \\
\text { to acceptable levels }\end{array}$ & 100.0 & 77.8 & 100.0 & 90.0 & 100.0 & 91.4 & 0.959 \\
\hline Hands washed thoroughly during handling products & 100.0 & 66.7 & 75.0 & 100.0 & 75.0 & 82.9 & 0.244 \\
\hline Utensils in contact with raw materials are sanitized & 100.0 & 100.0 & 100.0 & 100.0 & 87.5 & 97.1 & 0.457 \\
\hline
\end{tabular}

The restaurants in the Southeast region had the highest percentage of adequacy regarding the receipt of raw materials (88.6\%), followed by the South (79.0\%), Midwest (75.9\%), Northeast (75.8\%) and North regions (70.5\%). It is important to mention that most problems relating to meeting safety requirements were associated to the transport system (66.5\%), reception area $(75.5 \%)$, meat handling $(85.7 \%)$, and quality control (87.8\%), which showed the highest consistency.

When evaluating the influence of the number of meals served by the restaurants on the adherence to regulations, it was found that most of the facilities that were between 90.0 and $100.0 \%$ compliant were large restaurants. None of the small restaurants reached this percentage. This analysis reveals that, in our sample, the larger the restaurant, the more it met safety criteria for raw materials (Table 3 ).
Table 3 shows the classification of restaurants by region according to the adequacy of the items evaluated. It was found that more than half of university campus restaurants met between 70.0 and $90.0 \%$ of the requirements, but one restaurant in the North region and one Northeastern restaurant had adequacy below $50.0 \%$. It is noteworthy that almost all establishments with more than $90.0 \%$ compliance were located in the Southeast region.

\section{Discussion}

The restaurants rated represented a diverse sample of the university community, which confirms assertions about the increasing consumption of meals eaten outside of the home (Instituto Brasileiro de Geografia e Estatística, 2011). The demand for these services has grown significantly with the 
Table 3. Classification of university restaurants of Federal Institutions of Higher Education based on the conformity of quality parameters of meat at reception according to the size and the five different regions of Brazil.

\begin{tabular}{|c|c|c|c|c|c|}
\hline Classification $^{\mathrm{a}}$ & $\begin{array}{c}\text { Very Good } \\
n=8\end{array}$ & $\begin{array}{l}\text { Good } \\
n=20\end{array}$ & $\begin{array}{c}\text { Regular } \\
\mathrm{n}=5\end{array}$ & $\begin{array}{l}\text { Bad } \\
n=2\end{array}$ & $\begin{array}{c}\text { Too Bad } \\
\mathrm{n}=0\end{array}$ \\
\hline \multicolumn{6}{|l|}{ Size of restaurants } \\
\hline Small size & - & 15.0 & - & 50.0 & - \\
\hline Large size & 50.0 & 20.0 & 20.0 & 0.0 & - \\
\hline \multicolumn{6}{|l|}{ Regions of Brazil } \\
\hline Midwest & - & 15.0 & 20.0 & - & - \\
\hline Southeast & 62.5 & 20,0 & 20.0 & - & - \\
\hline South & 25.0 & 25.0 & 20.0 & - & - \\
\hline
\end{tabular}

Results in \%. a-Very Good - 91.0-100.0\%; Good - 70.0-90.0\%; Regular - 50.0-69.0\%; Poor - 20.0-49.0\%; Very Poor - 0.0-19.0\%.

implementation of the IFES support plan for the Restructure and Expansion of Federal Universities, which presents guidelines for the expansion of inclusive policies and student assistance (Brasil, 2008a).

The frequency of inclusion of meat in the menu in university campus restaurants resembles the data of the Household Budget Survey of 2008-2009, which shows that beef accounts for the highest quantity of calorie consumed, followed by chicken, sausages, pork, and fish (Instituto Brasileiro de Geografia e Estatística, 2010). The inclusion of meat in the menu meets the recommendations of daily intake of proteins (Brasil, 2008b). It is known that beef is among the five most common foods consumed in Brazil (Souza et al., 2013) and that meat is related to a great number of foodborne illness outbreaks (Brasil, 2011; Xue \& Zhang, 2013).

According to the law and to the results of the Brazilian university campus restaurants evaluated the need for the presence of a nutritionist to fulfil professional roles responsibilities is evident. With to the goal of ensuring the safety of the food produced, a nutritionist oversees the origin of the raw material as well as plans purchases and coordinates the receipt of the raw materials (Conselho Federal de Nutricionistas, 2006). The role of the nutritionist is related to the implementation of Good Practices and safe food production (Akutsu et al., 2005; Santos et al., 2012).

The Brazilian legislation and the Technical Standards have not established requirements for the training of the technical manager of food services, except for those places that require a legal supervision (Associação Brasileira de Normas Técnicas, 2008; Agência Nacional de Vigilância Sanitária, 2004), such as industrial kitchens and nutrition/dietetic services, which can are allowed to provide services only under the supervision of a nutritionist (Brasil, 1991; Conselho Federal de Nutricionistas, 2008).

Accordingly, it should be noted that proper supervision of raw material reception by qualified professionals is fundamental for the selection of suitable raw materials.

The criteria for the evaluation and selection of suppliers should be explicitly described by the food service (Agência
Nacional de Vigilância Sanitária, 2004). It is safe to purchase products that have been inspected and certified, preferably from establishments that have implemented quality control programs (Associação Brasileira de Normas Técnicas, 2008; Agência Nacional de Vigilância Sanitária, 2002). Most of the restaurants studied are managed by the IFES (Conselho Federal de Nutricionistas, 2006), in which the meat supplier is selected by the competitive bidding process. Therefore, the administrative system of the restaurants interferes with meat acquisition because the competitive bidding process limits the selection of suppliers and raw materials. Competitive bidding is aimed at purchasing assets and services with transparency, legality at the lowest prices. Among the modalities of the competitive bidding, the Electronic Bidding is a government strategy aimed to the rescue of transparent management with due respect to the interest and public property (Silva \& Bezerra, 2013). The lowest bidder will be selected to supply the product.

The food transport system is included as a criterion to be evaluated to ensure safety of the raw material (Agência Nacional de Vigilância Sanitária, 2002). Meat requires time and temperature control for safety to limit the proliferation of pathogenic microorganisms and toxin formation (Food and Drug Administration, 2009). It should be transported at the proper temperature and under appropriate hygienic conditions (Agência Nacional de Vigilância Sanitária, 2004). To ensure products integrity, vehicles must use control instruments that allow the maintenance of the proper temperature (Agência Nacional de Vigilância Sanitária, 2002). Therefore, their Food Transport License must be verified by the restaurants (Associação Brasileira de Normas Técnicas, 2008) because it verifies the suitability of the vehicle for the transportation of the product.

The receipt of raw materials should be performed in a protected area (safe from rain, sun, and dust) that is clean, free of obsolete or unrelated objects, and separated from other activities to avoid cross-contamination (Agência Nacional de Vigilância Sanitária, 2004). Federal health legislation includes standards for the design and construction of physical food service facilities.

Studies demonstrate non-compliance of food service hygiene and sanitation requirements. Inadequacies in floor 
drainage, protective screens over windows, record control, monitoring of the receipt of raw material, personal hygiene (Veiros et al., 2009), monitoring of vehicles' hygiene conditions, temperature control for perishable commodities, physical infrastructure for meat reception, and in the handling of reception by qualified staff were observed (Silva \& Cardoso, 2011).

The main deficiencies observed in the university restaurants evaluated were related to the implementation of preventive measures for the control of vectors and urban pests, which should be based on the installation of mechanical barriers (Associação Brasileira de Normas Técnicas, 2008; Codex Alimentarius Comission, 2003). Additionally, the presence of properly identified dedicated sinks suitable for personal hygiene (Agência Nacional de Vigilância Sanitária, 2004) and accessible to handlers at all times (Food and Drug Administration, 2009) was not present in all facilities studied hindering the fulfilment of the guidelines for proper handwashing (Agência Nacional de Vigilância Sanitária, 2004). Wu (2012) warns that the commitment of management team is extremely important for the implementation of strategies for food security.

Meat temperature must be checked upon receipt to ensure product safety (Associação Brasileira de Normas Técnicas, 2008; Agência Nacional de Vigilância Sanitária, 2002) because it is a parameter that greatly influences the proliferation of pathogens and spoilers (Chaves, 2012). In the present study, temperature control was not performed in all locations. However, almost all of the restaurants that have been performing inspection and approval of raw material considering the predefined criteria based on food safety (Agência Nacional de Vigilância Sanitária, 2004; 2002).

This study included the evaluation of cleaning, the integrity of the primary packaging, and the particularities of each food (Associação Brasileira de Normas Técnicas, 2008; Agência Nacional de Vigilância Sanitária, 2004), however, only a few restaurants adopted a meat packaging recycling program. Santos et al.( 2012) observed that lack of concern for environmental issues and non-compliance with the legislation regarding waste collection were evident. Only $29.7 \%$ of the facilities evaluated had implemented a system for the separation of recyclable materials.

The mandatory information on labels of packaged animal products, as established by Normative Instruction number $22 / 2005$, should include lot number, manufacturing date, expiration date, and type of storage (Brasil, 2005).Traceability is considered relevant since it can contribute to increase consumer confidence in food safety (Andrade et al., 2013). Labels have an important role in food choice since they offer a great deal of information on the nutrient contents of foods (Cavada et al., 2012). Traceability assures certain intrinsic characteristics of food products, their origin, and the certificates of quality management and safety systems (Nitzke et al., 2012).

The findings of this study concur with the general principles of food hygiene, which require the rejection of raw materials containing hazards that cannot be reduced to acceptable levels through preparation processes. The batches that do not meet the standards of quality and safety must be rejected and returned immediately to the supplier or properly identified and stored in a separate location until they can be sent to their final destination (Food and Drug Administration, 2009; Associação Brasileira de Normas Técnicas, 2008; Agência Nacional de Vigilância Sanitária, 2004).

The control measures adopted upon food reception must be proportional to real product safety risks. In order to ensure good condition for food preparation, laboratory tests should be performed on raw materials (Associação Brasileira de Normas Técnicas, 2008; Silva \& Bezerra, 2013). However, additional laboratory tests are not a reality in the majority of Brazilian university restaurants.

The personal hygiene of food handlers, including suitable, clean and appropriate clothing and adequate hand washing and disinfection, observed in most of the restaurants studied, is very important to ensure the hygienic and sanitary conditions of food (Silva \& Bezerra, 2013). These steps are essential to prevent foodborne illnesses since the lack of personal hygiene is one of the risk factors often associated with outbreaks (Food and Drug Administration, 2009). The same requirements for food handlers, such as adequate clothing and adoption of personal hygiene practices in accordance with health standards, should also be complied by the food suppliers (Associação Brasileira de Normas Técnicas, 2008; Agência Nacional de Vigilância Sanitária, 2004, 2002).

In the analysis of Good Practice procedures during meat receipt, higher levels of adequacy were observed for the restaurants located in the Southeast region of the country, which can be explained by the pioneering laws and regulations established by the State of São Paulo concerning Good Practices in food services (São Paulo, 1999, 2013).

The conditions in Brazilian university campus restaurants were better than those observed in a study by Veiros et al. (2009) on food services in a Portuguese university; the authors found an overall score of $62 \%$ of compliance with procedures related to food safety.

The relationship between the size of the university restaurant and the implementation of Good Practices confirms that there is a positive relationship between the number of students and the adequacy of food security procedures and operations. In food services located in Spain, it was found that small restaurants had the lowest performance levels in terms of food security management (Luning et al., 2013). The major food companies exhibited fewer non-compliance issues, most likely due to a greater awareness of the importance of following the principles of food safety (Losito et al., 2011).

\section{Conclusions}

IFES provide the university community with a significant number of daily meals. The campus restaurants are managed by either IFES or in partnership with third-party companies. The restaurants evaluated offered one or two different types of meat; the most commonly available were beef and chicken. 
The acquisition of raw material through competitive bidding in IFES-managed restaurants limits the selection of meat suppliers; therefore, restaurants should include the legal specifications in the competitive bidding announcement. Monitoring was carried out through a technical visit to the suppliers and a review of their past records.

It was concluded that the university campus restaurants, especially the larger facilities located in the Southeast region, meet most of the safety standards and legislation established to ensure the hygienic and sanitary conditions for the receipt of meat. However, it is evident that in some locations there are weaknesses pertaining to the suitability of the facility, the evaluation of the raw material transport system, and records and control measures for reception of meat.

\section{Acknowledgments}

The authors would like to thank the nutritionists of the IFES university restaurants evaluated who contributed providing relevant information to the present study and are grateful to Prof. Dr. Nelcindo Terra, of the Federal University of Santa Maria, for the critical review of article.

\section{References}

Agência Nacional de Vigilância Sanitária - ANVISA. (2002). Regulamento Técnico de Procedimentos Operacionais Padronizados aplicados aos estabelecimentos de alimentos e à lista de verificação das Boas Práticas de Fabricação em estabelecimentos produtores de alimentos (Resolução RDC nº 275, de 21 de outubro de 2002). Diário Oficial da República Federativa do Brasil.

Agência Nacional de Vigilância Sanitária - ANVISA. (2004). Regulamento Técnico de Boas Práticas para Serviços de Alimentação (Resolução RDC n ${ }^{216}$, de 15 de setembro de 2004). Diário Oficial da República Federativa do Brasil.

Akutsu, R. C., Botelho, R. A., Erika, B. C., Sávio, K. E. O., \& Araújo, W. C. (2005). Adequação das boas práticas de fabricação em serviços de alimentação. Revista de Nutrição, 18(3), 419-427. http://dx.doi. org/10.1590/S1415-52732005000300013

Almeida, A. C., Souza, R. M., Pinho, L., Macedo Sobrinho, E., \& Silva, B. C. M. (2010). Determinação de perigos microbiológicos em carnes bovinas resfriadas provenientes de abates clandestinos e comércio ilegal. Acta Veterinaria Brasilica, 4(4), 278-285.

Andrade, J. C., Deliza, R., Yamada, E. A., Galvão, M. T. E. L., Frewer, L. J., \& Beraquet, N. J. (2013). Percepção do consumidor frente aos riscos associados aos alimentos, sua segurança e rastreabilidade. Brazilian Journal of Food Technology, 16(3), 184-191. http://dx.doi. org/10.1590/S1981-67232013005000023

Associação Brasileira de Normas Técnicas - ABNT. (2008). NBR 15635:2008. Serviços de alimentação - Requisitos de Boas Práticas higiênico-sanitárias e controles operacionais essenciais. Rio de Janeiro: ABNT.

Brasil. (1991). Regulamenta a profissão de nutricionista e determina outras providências (Lei no 8.234 , de 17 de setembro de 1991). Diário Oficial da República Federativa do Brasil. Retrieved from http:// www.cfn.org.br/novosite/conteudo.aspx?IDMenu=56.

Brasil, Ministério da Agricultura, Pecuária e Abastecimento. (2005). Regulamento Técnico para Rotulagem de Produto de Origem Animal Embalado (Instrução Normativa n 22, de 24 de novembro de 2005). Diário Oficial da República Federativa do Brasil.
Brasil, Ministério da Educação e Cultura, Secretaria de Educação Superior Diretoria de Desenvolvimento das Instituições Federais de Ensino Superior (2008a). Programa de Apoio a Planos de Reestruturação e Expansão das Universidades Federais. Reuni 2008 - Relatório de Primeiro Ano. Brasília: Ministério da Educação e Cultura. Retrieved from http://pt.scribd.com/doc/55220425/ reuni-relatorio.

Brasil, Ministério da Saúde, Secretaria de Atenção à Saúde, Coordenação-Geral da Política de Alimentação e Nutrição (2008b). Guia alimentar para a população brasileira: promovendo a alimentação saudável. (Série A. Normas e Manuais Técnicos). Brasília: Ministério da Saúde. Retrieved from http://bvsms.saude.gov.br/ bvs/publicacoes/guia_alimentar_populacao_brasileira_2008.pdf.

Brasil, Ministério da Saúde, Secretaria da Vigilância em Saúde - SVS. (2011). Dados Epidemiológicos - DTA. Período de 2000 a 2011. Brasília: Ministério da Saúde. Retrieved from http://portal.saude. gov.br/portal/arquivos/pdf/dados_dta_periodo_2000_2011_site. pdf.

Cavada, G. S., Paiva, F. F., Helbig, E., \& Borges, L. R. (2012). Rotulagem nutricional: você sabe o que está comendo? Brazilian Journal of Food Technology, 15, 84-88. http://dx.doi.org/10.1590/S198167232012005000043

Chaves, R. (2012). Gas-producing and spoilage potential of Enterobacteriaceae and lactic acid bacteria isolated from chilled vacuum-packaged beef. International Journal of Food Science \& Technology, 47(8), 1750-1756. http://dx.doi.org/10.1111/j.13652621.2012.03030.x

Codex Alimentarius Comission - CAC. (1993). Código de Prácticas de Higiene para los Alimentos Precocinados y Cocinados utilizados em los Servicios de Comidas para Colectividades. CAC/RCP-39. Retrieved from http://www.codexalimentarius.org/normas-oficiales/lista-delas-normas/es/.

Codex Alimentarius Comission - CAC. (2003). Principios Generales de Higiene de los Alimentos. Retrieved from http://www. codexalimentarius.org/normas-oficiales/lista-de-las-normas/es/.

Codex Alimentarius Comission - CAC. (2009). Higiene de los alimentos: Principios Generales de Higiene de los Alimentos (4. ed.). Roma: FAO/ OMS. Retrieved from ftp://ftp.fao.org/codex/Publications/Booklets/ Hygiene/FoodHygiene_2009s.pdf.

Conceição, F. V. E., \& Gonçalves, E. C. B. A. (2009). Qualidade físicoquímica de mortadelas e carnes moídas e conhecimento dos consumidores na conservação destes produtos. Brazilian Journal of Food Technology, 29(2), 283-290.

Conselho Federal de Nutricionistas (2008). Dispõe sobre critérios para assunção da responsabilidade técnica no exercício das atividades do nutricionista e dá outras providências (Resolução no 419 de 19 de março de 2008). Diário Oficial da República Federativa do Brasil.

Conselho Federal de Nutricionistas. (2006). Dispõe sobre a definição das áreas de atuação do nutricionista, sua atribuição e estabelece parâmetros numéricos de referência, por área de atuação, e dá outras providências (Resolução no 380, de 28 de dezembro de 2005). Diário Oficial da República Federativa do Brasil.

Ebone, M. V., Cavalli, S. B., \& Lopes, S. J. (2011). Segurança e qualidade higiênico-sanitária em unidades produtoras de refeições comerciais. Revista de Nutrição, 24(5), 725-734. http://dx.doi.org/10.1590/ S1415-52732011000500006

Esperança, L. C., \& Marchioni, D. M. L. (2011). Qualidade na produção de refeições em restaurantes comerciais na região de Cerqueira César, São Paulo. Nutrire: revista da Sociedade Brasileira de Alimentação e Nutrição, 36(1), 71-83. 
Food and Drug Administration - FDA. (2009). Public Health Service. Food Code: Recommendations of the United States Public Health Service Food and Drug Administration. Retrieved from http:// www.fda.gov/Food/FoodSafety/RetailFoodProtection/FoodCode/ FoodCode2009/.

Instituto Brasileiro de Geografia e Estatística - IBGE. (2010). Pesquisa de Orçamentos Familiares 2008-2009: Avaliação nutricional da disponibilidade domiciliar de alimentos no Brasil. Rio de Janeiro: IBGE. Retrieved from http://biblioteca.ibge.gov.br/visualizacao/ livros/liv47310.pdf.

Instituto Brasileiro de Geografia e Estatística - IBGE. (2011). Pesquisa de Orçamentos Familiares. 2008-2009: Análise de consumo alimentar pessoal no Brasil. Rio de Janeiro: IBGE. Retrieved from http:// www.ibge.gov.br/home/estatistica/populacao/condicaodevida/ pof/2008_2009_analise_consumo/pofanalise_2008_2009.pdf.

Lopes, L. F. D., Müller, I., Souza, A. M., Ansuj, A. P., Moraes, D. A. O., Moreira Júnior, F. J., Pulgati, F. H., \& Strazzabosco, F. (2008). Estatística geral (3. ed.). Santa Maria: UFSM, CCNE.

Losito, P., Visciano, P., Genualdo, M., \& Cardone, G. (2011). Food supplier qualification by an Italian Large-scale-Distributor: Auditing system and non-conformances. Food Control, 22, 2047-2051. http:// dx.doi.org/10.1016/j.foodcont.2011.05.027

Luning, P. A., Chinchilla, A. C., Jacxsens, L., Kirezieva, K., \& Rovira, J. (2013). Performance of safety management systems in Spanish food service establishments in view of their context characteristics. Food Control, 30, 331-340. http://dx.doi.org/10.1016/j. foodcont.2012.06.040

Medeiros, L. B., Saccol, A. L. F., Delevati, M. T. S., \& Brasil, C. C. (2012). Diagnóstico das condições higiênicas de serviços de alimentação de acordo com a NBR 15635:2008. Brazilian Journal of Food Technology, 15, 47-52. http://dx.doi.org/10.1590/S1981-67232012005000035

Nitzke, J. A., Thys, R., Martinelli, S., Oliveiras, L. Y., Augusto-Ruiz, W., Penna, N. G., \& Noll, I. B. (2012). Segurança alimentar: retorno às origens? Brazilian Journal of Food Technology, 15, 2-10. http://dx.doi. org/10.1590/S1981-67232012005000044

Saccol, A. L. F., Stangarlin, L., \& Hecktheuer, L. H. (2012). Instrumentos de apoio para implantação de Boas Práticas em empresas alimentícias. Rio de janeiro: RUBIO.

Santos, L. L., Akutsu, R. C. C. A., Botelho, R. B. A., \& ZandonadI, R. P. (2012). Cumprimento das normas ISO 14001 e ISO 22000 por serviços de alimentação. Revista de Nutrição, 25(3), 373-380. http:// dx.doi.org/10.1590/S1415-52732012000300007

São José, J. F. B., Coelho, A. I. M., \& Ferreira, K. R. (2011). Avaliação das boas práticas em unidade de alimentação e nutrição no município de Contagem-MG. Alimentação e Nutrição, 22(3), 479-487.
São Paulo, Secretaria de Estado da Saúde. (1999). Regulamento técnico sobre os parâmetros e critérios para o controle higiênico-sanitário em estabelecimentos de alimentos (Portaria CVS nº 06, de 10 de março de 1999). Diário Oficial do Estado de São Paulo. Retrieved from http://www.cvs.saude.sp.gov.br/zip/E_PT-CVS-06_100399. pdf.

São Paulo, Secretaria de Estado da Saúde. (2013). Aprova o regulamento técnico sobre boas práticas para estabelecimentos comerciais de alimentos e para serviços de alimentação e o roteiro de inspeção (Portaria CVS nº 05 de 09 de abril de 2013). Diário Oficial do Estado de São Paulo.

Silva, J. M. S., \& Bezerra, A. C. A. (2013). As peculiaridades do sistema de registro de preços em menção ao novo Decreto n 7.892/2013. Revista Âmbito Jurídico, 115. Retrieved from http://www.ambitojuridico.com.br/site/?n_link=revista_artigos_leitura\&artigo_ $\mathrm{id}=13505 \&$ revista_caderno $=4$.

Silva, V. B., \& Cardoso, R. C. (2011). Controle da qualidade higiênicosanitária na recepção e no armazenamento de alimentos: um estudo em escolas públicas municipais de Salvador, Bahia. Segurança Alimentar e Nutricional, 18(1), 43-57.

Souza, A. M., Pereira, R. A., Yokoo, E. M., Levy, R. B., \& Sichieri, R. (2013). Most consumed foods in Brazil: National Dietary Survey 2008-2009. Revista de Saúde Pública, 47(1), 190-199. http://dx.doi. org/10.1590/S0034-89102013000700005

Veiros, M. B., Proença, R. P. C., Santos, M. C. T., Kent-Smith, L., \& Rocha, A. (2009). Food safety practices in a Portuguese canteen. Food Control, 20, 936-941. http://dx.doi.org/10.1016/j. foodcont.2009.02.002

World Health Organization - WHO. (2009). Assuring food safety and quality: guidelines for strengthening national food control systems. Retrieved from http://www.who.int/foodsafety/publications/ capacity/en/Englsih_Guidelines_Food_control.pdf

Wu, S. (2012). Factors influencing the implementation of food safety control systems in Taiwanese international tourist hotels. Food Control, 28, 265-272. http://dx.doi.org/10.1016/j. foodcont.2012.05.038

Xue, J., \& Zhang, W. (2013). Understanding China's food safety problem: An analysis of 2387 incidents of acute foodborne illness. Food Control, 30, 311-317. http://dx.doi.org/10.1016/j. foodcont.2012.07.024

Youn, S., \& Sneed, J. (2003). Implementation of HACCP and prerequisite programs in school foodservice. Journal of the American Dietetic Association, 55(103), 55-60. PMid:12525794. http://dx.doi. org/10.1053/jada.2003.50002 